Primljen / Received: 16.1.2014. Ispravljen / Corrected: 25.5.2014. Prihvaćen / Accepted: 17.6.2014. Dostupno online / Available online: 1.8.2014.

\title{
Design of vehicle actuated signal using simulation
}

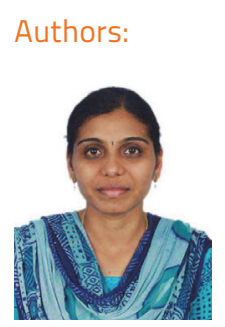

${ }^{1}$ Nithya Swaminathan, BSc. CE. nithya@measiarch.net

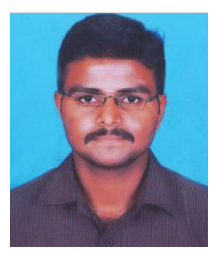

${ }^{1}$ Nithyanandhan Rathinavel, BSc. CE. royalcivil.nithi@gmail.com

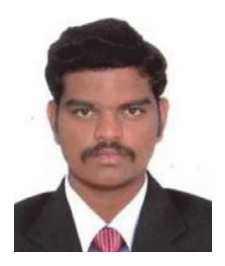

${ }^{1}$ Senthurkumar Duraisamy, BSc. CE. dsenthurkumar@live.com

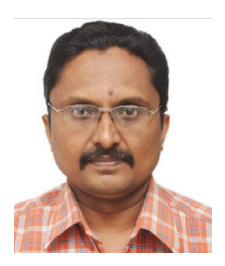

${ }^{1}$ Assoc.Prof.Gunasekaran Karuppanan, PhD. CE kgunasekaran@hotmail.com

\section{${ }^{1}$ Anna University}

Division of Transportation Engineering

Tamil Nadu, India

\author{
Professional paper \\ Nithya Swaminathan, Nithyanandhan Rathinavel, Senthurkumar Duraisamy, Gunasekaran \\ Karuppanan \\ Design of vehicle actuated signal using simulation
}

Most of the cities in India have fixed time signal settings and it is operated manually during peak hours. Existing strategies that are used in Indian cities does not offer considerable benefits in reducing the delays of all vehicles. The Vehicle Actuated Programming has the ability to provide control strategies in response to the real-time traffic conditions. Simulation based model for a major arterial in Chennai is developed using Vehicle Actuated Programming which detects vehicle presence and arrivals to modify the signal timings. The simulation results were compared with the existing traffic operations to understand the benefits.

Key words:
vehicle actuated programming, fixed time, VISSIM simulation, delay, coordination

Stručni rad

Nithya Swaminathan, Nithyanandhan Rathinavel, Senthurkumar Duraisamy, Gunasekaran Karuppanan

\section{Simulacijski model prometno ovisnih signalnih uredaja}

U većini gradova u Indiji koriste se semafori s fiksnom duljinom ciklusa, a promet se regulira ručno u satima vršnog prometa. Strategije koje se sada koriste u indijskim gradovima ne omogućuju bitno smanjenje vremena kašnjenja vozila. Prometno-ovisno upravljanje prometom omogućuje primjenu strategija za trenutno usklađivanje sa stvarnim uvjetima u prometu. Simulacijski model za gradnju cestovne arterije u Chennai-ju razvijen je primjenom prometnoovisnog sustava upravljanja prometom koji otkriva prisustvo vozila na raskrižju i u skladu s time mijenja duljinu ciklusa. Rezultati simulacije uspoređeni su s postojećim stanjem da bi se uočile prednosti prometno-ovisnog upravljanja.

\section{Ključne riječi:}

prometno ovisno upravljanje prometom, fiksna duljina ciklusa, simulacija VISSIM-om, kašnjenje, koordinacija

Fachbericht

Nithya Swaminathan, Nithyanandhan Rathinavel, Senthurkumar Duraisamy, Gunasekaran Karuppanan

\section{Simulationsmodell zur verkehrsabhängigen Signalplanung}

Diemeisten Städtein Indien habenzeitlich bestimmteSignaleinstellungen, diein der Hauptverkehrszeit manuell angepasst werden. Derzeitige Strategien dienen daher nicht zur Reduzierung von Verkehrsverzögerungen. Die verkehrsabhängige Programmierung ermöglicht Kontrollstrategien in Bezug auf momentane Verkehrszustände. Für eine der Hauptverkehrsrichtungen in Chennai ist diesbezüglich ein Simulationsmodell entwickelt, so dass die Anfahrt von Fahrzeugen erkannt und die Signaleinstellung entsprechend modifiziert werden kann. Simulationsresultate sind mit den bestehenden Verkehrseinstellungen verglichen, um entsprechende Vorteile zu erkennen.

Schlüsselwörter:

verkehrsabhängige Programmierung, Zeitbestimmung, VISSIM Simulation, Verzögerung, Koordination 


\section{Introduction}

With an overall traffic growth on urban highways and arterials, congestion is becoming a significant problem with major negative impacts on all vehicles. These negative impacts often result in increased travel times, poor reliability, and unpredictable on-time performance, crowding, and longer waiting times, mainly due to the police control strategy at intersections. To overcome these drawbacks, the traffic actuated control is necessary as it allows cycle length adjustment based on the real time traffic with a continuous vehicle detection system [1]. The fixed time control requires definition of time for each phase, whereas an actuated programming allows intersection optimization [2].

The Vehicle Actuated Programme helps in modifying the normal signal process for better accommodation of vehicles, which improves the schedule adherence, and the operational and road efficiency. In its basic form, it is clear that the Vehicle Actuated Programme is a sophisticated approach at the street network level, as it properly accommodates vehicles, based on their service requirements. But, the changing detector configuration and loop size, logical grouping of signal phases, and the use of dummy phases, must be analyzed in detail before implementation of vehicle actuated programming [3].

The vehicle actuated programming was found to be adequate for individual intersection performance [4]. The reliability of implementation of the vehicle actuated programme along a corridor depends on the traffic flow characteristics, geometry, cross street volume, and signal settings $[5,6]$. The impact of flow on the cross street [7] must be studied in detail before implementation of the vehicle actuated programming. When properly analyzed and implemented, it provides an effective long term measure with signal optimization [8] through automatic adjustment of signal timings with the change in flow $[9,10]$.

Several studies have been conducted to evaluate effectiveness of vehicle actuated programming at various intersections. Very few researches evaluated the performance of vehicle actuated programming [11] under heterogeneous conditions for a corridor. Hence, there is a need to evaluate the benefits of vehicle actuated programming in signal optimization for corridors.
This paper describes a microscopic simulation study that evaluates the benefits of implementing predictive VAP along an urban arterial in Chennai, India. The proposed methodology consist of three components: a) delay estimation for existing fixed time condition, b) Estimation of delay at the intersections with Vehicle Actuated Signals and c) Estimation of delay with signal coordination (fixed time). The simulation results indicate that in periods of smaller demand, the overall possible negative impacts could be neglected due to the advantage of consumption of unused capacity at the intersection.

\section{Study area}

A stretch of $3.1 \mathrm{~km}$ on Anna Salai, which is a major arterial road in Chennai city, was selected as study area (Figure 1). Anna Salai (previously called Mount Road) is a six lane divided road built to facilitate smooth flow of traffic. However, with the development of educational institutions and commercial activities, heavy flow of vehicles is observed during peak hours. The study area has five signalised intersections viz., Thiruveka Road Junction, Smith Road Junction, Spencer Junction, Wellington plaza Junction and Wallajah Road Junction.

\section{Current traffic scenario}

The classified volume count was made at the five intersections from 7.00 hours to 12.00 hours with the assistance of volunteers. The morning peak hour traffic flow was obtained from field observations. The peak hour flow at the intersections is given in Table 1. The traffic composition observed was $37 \%$ cars , $45 \%$ two - wheleers (only motorised), $8 \%$ buses and $10 \%$ auto rickshaws. The traffic flow at the intersections is manually regulated during peak hours, while at other periods the traffic is regulated via isolated fixed time signals.

The travel time study was conducted during the morning peak hour by running the test vehicle fitted with GPS. 12 runs were performed with the test vehicle. The time space diagram for the first sample run is shown in Figure 2. The vehicle is considered as stopped if its speed is less than $2.5 \mathrm{~km} / \mathrm{h}$ [12]. The profiles given in Figure 2 are original data without the smoothening process. The computation

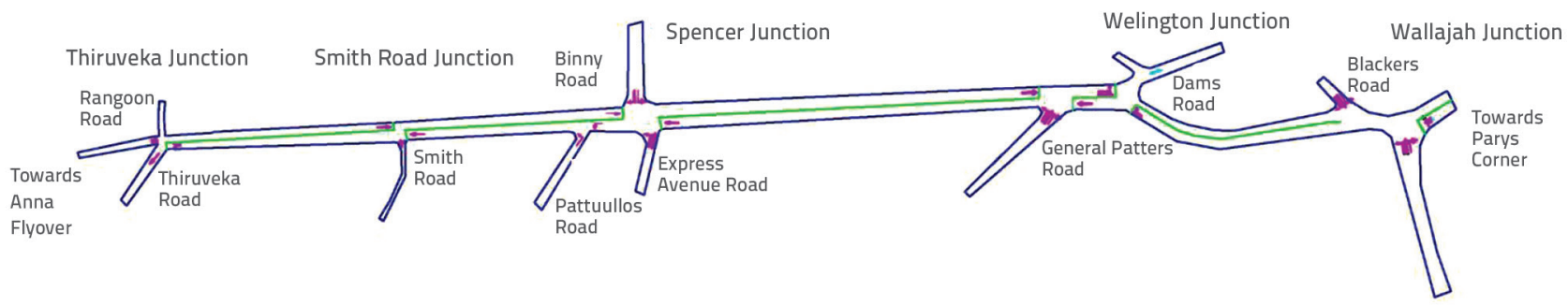

Figure 1. Study area 
of control delay [12] was conducted by summing-up of all three delay components. Table 2 shows the proportion of deceleration, stopped and acceleration delays.

Table 1. Intersection volume in vehicles/hour

\begin{tabular}{|l|c|c|}
\hline Name of Intersection & $\begin{array}{c}\text { Flow in } \\
\text { vehicles/hour }\end{array}$ & Flow in PCE/h \\
\hline Thiruveka Junction & 8883 & 7861 \\
\hline Smith Junction & 7086 & 6661 \\
\hline Spencer Junction & 12.344 & 11.110 \\
\hline Wellington Junction & 7881 & 6187 \\
\hline Wallajah Junction & 11.624 & 10.682 \\
\hline
\end{tabular}

Two Video graphic cameras were fixed at elevated locations at the Spencer intersection in order to record the arrival time of vehicles, cycle time duration, green time duration, and departure time of vehicles. The cameras were focussed to record movements of the vehicles that arrived from Smith Road junction to Spencer intersection. The arrival time, departure time of test vehicle, and the corresponding cycle time and green time of the phase, were obtained from video recordings. The arrival and departure timings were also checked using clock timings of the GPS records. As it was the morning peak hour, traffic movements at the intersection were regulated by traffic police (manually controlled). The cycle time and green time for each phase was different. The cycle time during manual operation at Spencer intersection varied from 134 seconds to 288 seconds (Average cycle time $=192$ seconds).

Table 2. Acceleration, stopped and deceleration delay measured at Spencer Intersection

\begin{tabular}{|l|c|c|c|c|}
\hline Run No: & $\begin{array}{c}\text { Acceleration delay } \\
{[\mathrm{s}]}\end{array}$ & $\begin{array}{c}\text { Stopped delay } \\
{[\mathrm{s}]}\end{array}$ & $\begin{array}{c}\text { Deceleration delay } \\
{[\mathrm{s}]}\end{array}$ & $\begin{array}{c}\text { Control delay } \\
{[\mathrm{s}]}\end{array}$ \\
\hline RUN 1 & 15,53 & 33,5 & 17,46 & 66,49 \\
\hline RUN 2 & 14,94 & 40,75 & 11,48 & 69,27 \\
\hline RUN 3 & 12,4 & 44,75 & 10,22 & 68,63 \\
\hline RUN 4 & 20,09 & 48,5 & 11,03 & 78,81 \\
\hline RUN 5 & 15,22 & 82 & 7,44 & 108,25 \\
\hline RUN 6 & 7,92 & 48,25 & 13,28 & 63,61 \\
\hline RUN 7 & 4,61 & 64,5 & 7,35 & 82,39 \\
\hline RUN 8 & 17,31 & 53,25 & 17,3 & 77,91 \\
\hline RUN 9 & 9,47 & 52,25 & 8,18 & 79,02 \\
\hline RUN 10 & 10,69 & 50,5 & 8,3 & 69,37 \\
\hline RUN 11 & 13,92 & 61 & 10,46 & 83,22 \\
\hline RUN 12 & 7,16 & 67,75 & 85,37 \\
\hline
\end{tabular}

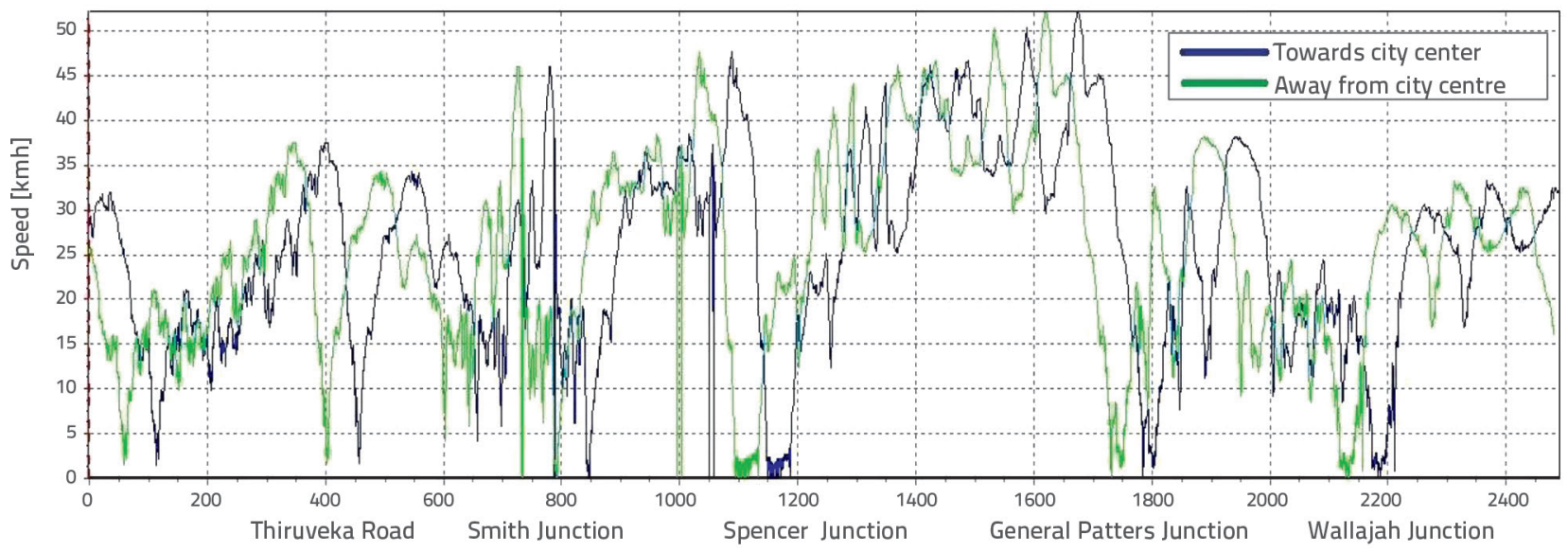

Figure 2. Speed profile of a typical run during morning peak hour 
It was observed that the stopped delay varied with the time of arrival in a cycle. An attempt was made to relate the stopped delay to cycle time ratio, and the arrival time to cycle time ratio. The plot of D/C Ratio to the A/C Ratio of the test vehicle observed at Spencer Intersection is shown in Figure 3. The plot indicates that if a vehicle arrives at the beginning of the red time, the $A / C$ ratio will be minimum and the proportion of stopped delay with respect to cycle time would be higher. For example, consider an intersection with a cycle time of 140 seconds and a green time for the approach road as 45 seconds. If a vehicle arrives 10 seconds after commencement of the red phase the $A / C$ ratio would be $10 / 140=0.07$, and the proportion of stopped delay would be more than $50 \%$ of the cycle time i.e. minimum 70 seconds. For the above intersection, if the vehicle arrives at the $100^{\text {th }}$ second after commencement of the cycle (i.e. at the $5^{\text {th }}$ second of the green phase) the vehicle would undergo a minimum stopped delay of about 10 seconds. Using the above plot, the delay of each vehicle could be calculated if the arrival pattern of vehicles and cycle time is known. This strategy could be adopted especially for estimation of stopped delay of vehicles entering manually controlled intersections.

The total measured stopped delay for vehicles moving from Thiruveka Junction to Wallajah Junction was around $110 \mathrm{sec}$, and it was around $87 \mathrm{sec}$ for reverse direction

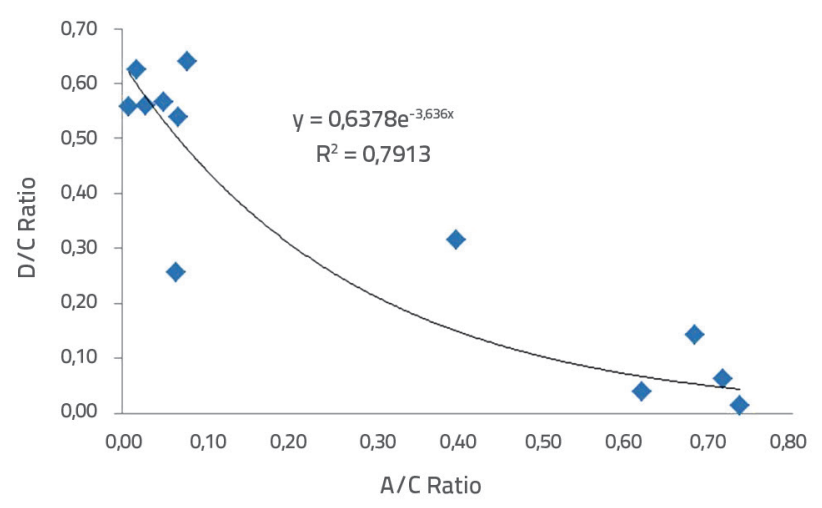

Figure 3. Plot of $D / C$ with $A / C$ Ratio

The travel pattern of vehicles in the study area (i.e. the entry intersection, path, and exit intersection) was obtained by matching the registered number plates of vehicles. The signal cycle timings adopted for simulation according to this scenario were based on the concept that no vehicle should wait more than 120 seconds. Travel pattern details were used to define the routing (path of vehicles in the road network) for simulation.

\section{Simulation model development}

VISSIM 5.3 was used for model development. The steps involved in developing the simulation model are:
- Import of background image of the study area.

- Building the road network using background image with links and connectors.

- Definition of vehicle types and classes using the vehicle parameters module.

- Definition of traffic compositions observed at entry points of the study area.

- Definition of speed distributions developed with observed data for each vehicle.

- The routing was defined based on the observed travel pattern of vehicles entering and leaving the study area. The routing is the route the vehicle would choose to reach the destination from an origin. Twelve entry and exit locations of the study area were taken as 12 traffic zones. The travel pattern in the study was defined as a $12 \times 12$ OD matrix.

- Traffic signal controls were defined in VISSIM using the internal fixed time controller/VAP Controller. Signal heads were placed in the model to represent available stop lanes.

- Data collection points were added to the network to correspond with actual data collection points for output.

\subsection{Vehicle Actuated Programming}

Signal timings of fixed controllers were obtained from the Chennai City Traffic Police. VAP module was costomised as:

1. Defining vehicle detection zone by placing two detectors for each lane at each approach. The detectors sensed the presence/absence of vehicles in between them.

2. Setting variable phase time by estimating the clearance time required for detected vehicles. When no vehicle was detected for 5 seconds between the detectors that particular phase was truncated. In each phase, a minimum time was set for safe clearance of vehicles. Also, a maximum time limit was set for the end of the phase if a continuous flow was detected.

\subsection{Model validation}

The observed traffic flow at intersections was compared with the traffic flow from the model, and it was established that the difference was less than $10 \%$. The model was therefore considered valid. For example, the flow observed at Spencer intersection during the morning peak hour was 12938 vehicles, whereas the vehicle count from the simulated model amounted to 11825 vehicles (Table 3). The difference was $9.4 \%$.

\section{Scenario formulation}

Scenarios were formulated to compare the performance of Vehicle Actuated Signals with the fixed time signals. They are as follows. 
Table 3. Validation of simulation model to existing condition

\begin{tabular}{|c|c|c|c|}
\hline \multirow{2}{*}{ Street } & \multirow{2}{*}{ Vehicle movement } & \multicolumn{2}{|c|}{ Number of vehicles / hour } \\
\hline & & Simulated condition & Existing condition \\
\hline \multirow{3}{*}{ Gemini } & Left & 647 & 784 \\
\hline & Through & 2499 & 2517 \\
\hline & Total & 3146 & 3301 \\
\hline \multirow{3}{*}{ EA } & Left & 311 & 328 \\
\hline & Right & 246 & 249 \\
\hline & Total & 557 & 577 \\
\hline \multirow{3}{*}{ Binny } & Left & 276 & 295 \\
\hline & Right & 3186 & 3926 \\
\hline & Total & 3462 & 4221 \\
\hline \multirow{4}{*}{ LIC } & Left & 100 & 94 \\
\hline & Through & 4104 & 4207 \\
\hline & Right & 456 & 538 \\
\hline & Total & 4660 & 4839 \\
\hline & Total & 11825 & 12938 \\
\hline
\end{tabular}

\subsection{Scenario 1: Existing condition with fixed time signal}

The network was loaded with the observed morning peak hour flow of traffic. Fixed time signal settings preferred for the morning peak hour were used. The phasing pattern and timing are shown in Figure 4.

The maximum cycle time and green time set in intersection controllers for fixed time signal operation (Scenario 1) and co-ordination of fixed time signals (Scenario 3) are given in Figure 4. The level of saturation (i.e., V/C ratio) at the Spencer intersection for the above fixed signal timings was 1.74. The level of saturation, i.e. V/C ratio for the intersection, was calculated using Equation (1) [13]:

$\mathrm{V} / \mathrm{C}=\sum_{i=1}^{n} \frac{V_{i}}{C_{i}}$

where:

$$
C_{i}=\frac{g_{i}}{C} s_{i}
$$

n $\quad-$ No. of phases

$v_{i} \quad-$ Critical flow, PCE/h

$c_{i}$ - capacity of the critical lane group for the phase, PCE/h

S. - Saturation flow rate for the critical lane group, PCE/h

$g_{i} \quad-$ Effective green time for the critical lane group in seconds

C - Cycle time in seconds

$\mathrm{PCE} / \mathrm{h}$ - Passenger car equivalent in hour
The control delay which includes acceleration delay, stopped delay, and deceleration delay, for all intersections is given in Figure 6. It was observed that the majority of vehicles cleared the intersection in the second cycle. The green time was not sufficient to clear all the vehicles accumulated during the red phase and those arriving during the green time. During manual control the police extended or reduced the green time based on the time required for the accumulated vehicles to clear. It was therefore observed that the delay for the maximum signal timings of the fixed time signal scenario was higher than that observed during manual operation.

\subsection{Scenario 2: Vehicle actuated signal}

The Vehicle Actuated Signal (VAS) as described in Section 4.2 was designed for all intersections. A variable cycle time / variable phase timing model was attempted for the intersections. A view of sample vehicle actuated timings for Thiruveka Junction is given in Figure 5.

The cycle time during the vehicle actuated scenario for Spencer Intersection varied from 127 seconds to 269 seconds. The controlled delay at the intersections for the scenario was significantly lower than that of the fixed time signal scenario (Figure 6).

\subsection{Scenario 3: Coordination of fixed time signals}

The Spencer Intersection was the critical intersection. The cycle time of critical intersection was adopted for all intersections, 


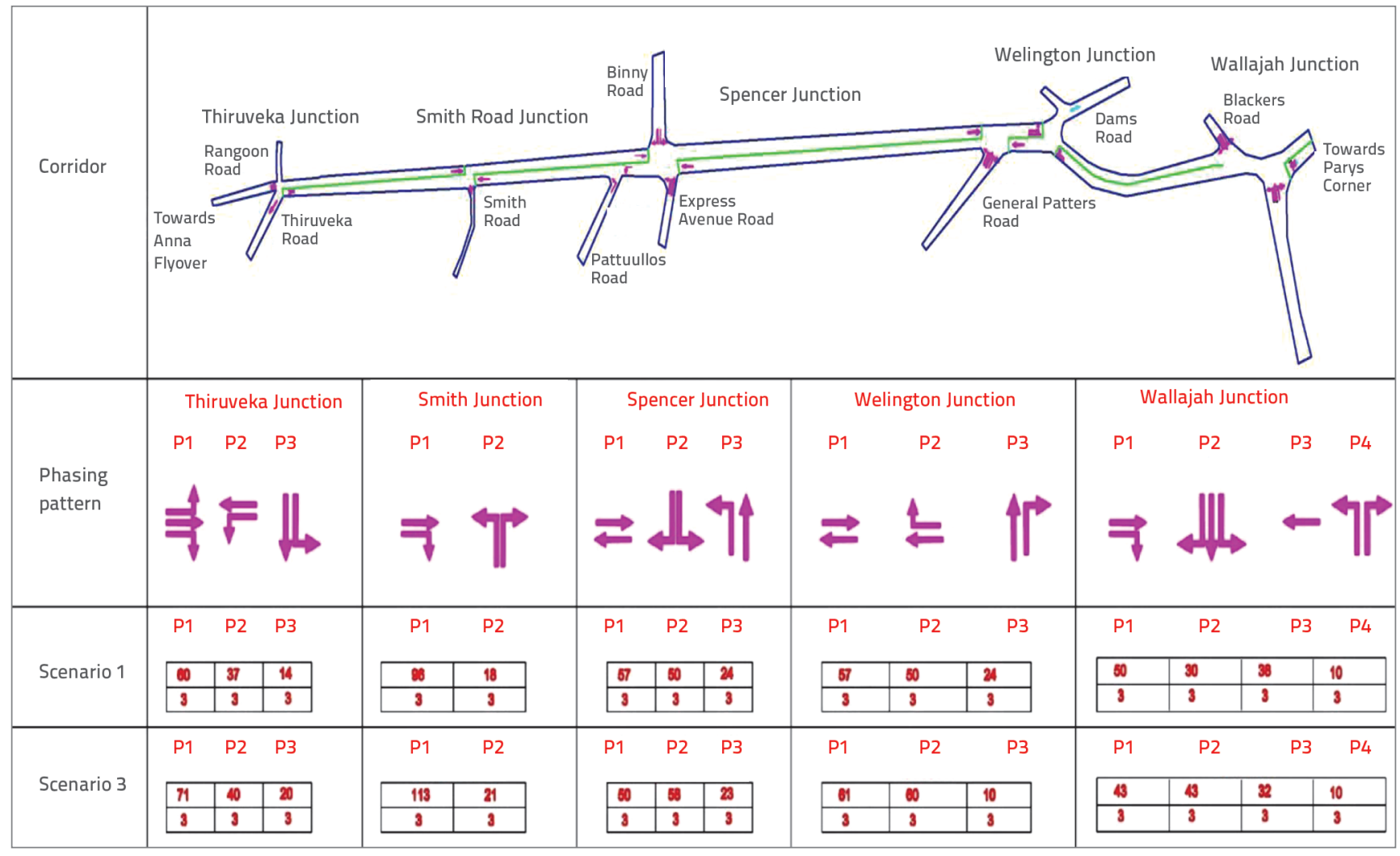

Figure 4. Fixed time signal settings for scenarios 1 and 3

and coordination of movement of vehicles towards Parrys was attempted. The offset timing for the signals, assuming the vehicle speed of $30 \mathrm{~km} / \mathrm{h}$, was considered for coordination. The phasing pattern and timing are shown in Figure 4.

\section{Result and discussion}

\subsection{Comparison of Vehicle Actuated Signal with fixed timings}

An average delay per vehicle determined from the simulation would give the intersection performance (Figure 6). The individual intersection performance shows significant reduction in delay to about $28 \%$ if vehicle actuated signals are adopted. The reduction in intersection delay for Scenario 2 varied from $20 \%$ to $39 \%$ when compared to Scenario 1. At the critical intersection, i.e. Spencer Intersection, the delay reduction amounted to $39 \%$.

\subsection{Comparison of fixed time signals with coordination of fixed timing signals}

An average delay per vehicle determined from the simulation enabled understanding of the intersection performance (Figure 7). The cycle time of the signals, i.e. the cycle time required for critical intersection, was assumed to be 140 seconds. The speed of the traffic flow was assumed as 30 $\mathrm{km} / \mathrm{h}$. On coordination of signals, an average $8 \%$ reduction in delay is possible when compared to Scenario 1. Similarly if coordination of Vehicle actuated signals is attempted, a better reduction in delay can be realised.

\section{Conclusion}

Vehicle actuated signals are proposed as a replacement for the existing fixed time signals. A simulation was made to test performance of fixed time and vehicle

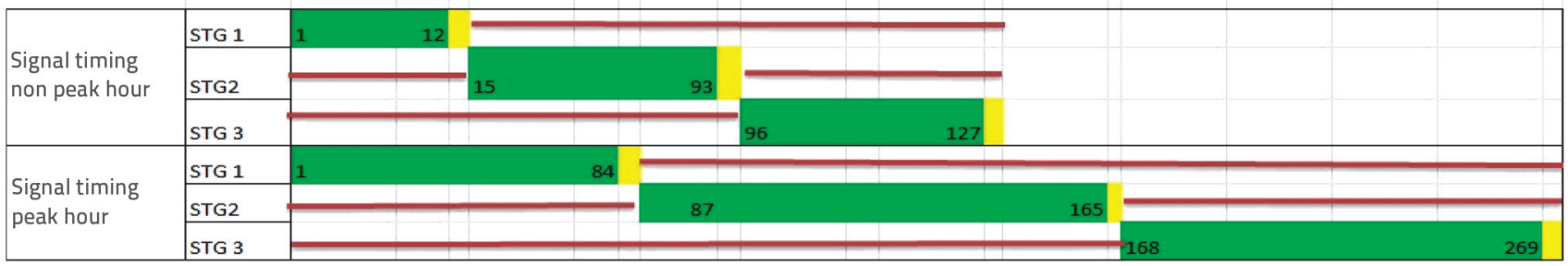

Figure 5. Sample VA signal Timings - Thiruveka Junction 


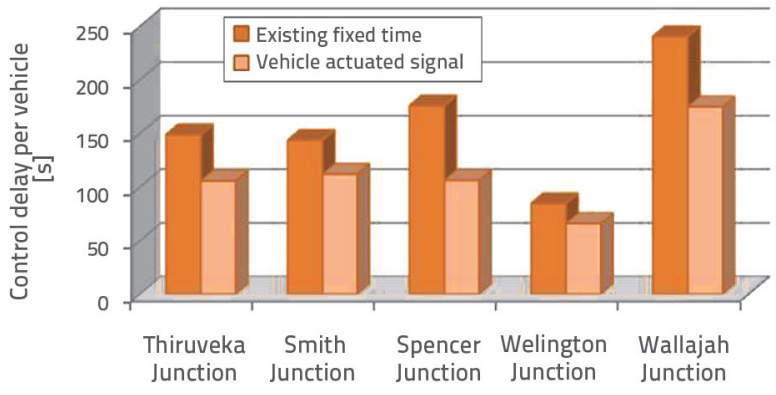

Figure 6. Comparision of fixed time with vehicle actuated signal

actuated signals. $28 \%$ delay reduction is possible with the implementation of vehicle actuated signals. Further reduction is possible if a coordination of vehicle actuated signals is attempted.

With technological developments such as the Virtual Loop Camera, it is possible to make use of vehicle actuated signals. Delay times will considerably be reduced If vehicle actuated signals are designed and used for traffic control.

\section{REFERENCES}

[1] Feng-Bor Lin.: Knowledge Base on Semi-Actuated TrafficSignal Control. Journal of Transportation Engineering, Vol. 117, No. 4, 1991. (doi: http://dx.doi.org/10.1061/(ASCE)0733947X(1991)117:4(398))

[2] Cassidy, M.J., Chuang Y.H., Vitale, J.: Reexamining Vehicle Actuation Strategies At Isolated Signalized Intersections. Journal of Transportation Engineering, American society of Civil Engineers, Vol. 122, pp. $235-240,1996$.

[3] Ravikumar, P., Mathew, T.V.: Vehicle-Actuated signal Controller For Heterogeneous Traffic Having Limited Lane discipline, Journal of Intelligent Transportation Systems, pp. 44 - 53, 2011.

[4] Bruce X Wang, et al.: Vehicle Actuated Signal Performance Under General Traffic at an Isolated Intersection, 2010.

[5] Yun, I., Park, B.: Stochastic Optimization for Coordinate Actuated Traffic Signal Systems. Journal of Transportation Engineering, American society of Civil Engineers, Vol. 137, No. 7, 2012, pp. 819-829, 2012.

[6] Park, B., Chen, Y.: Quantifying the Benefits of Coordinated Actuated Traffic Signal Systems: A Case Study., VTRC 11-CR2, 2010.

[7] Dixon, M.: Development of New Actuated signalized Intersection Performance measurement Methodologies Using Traffic Controller Input and Output Data. National Institute for Advanced Transportation Technology. University of Idaho. KLK120, N08-14, 2008.

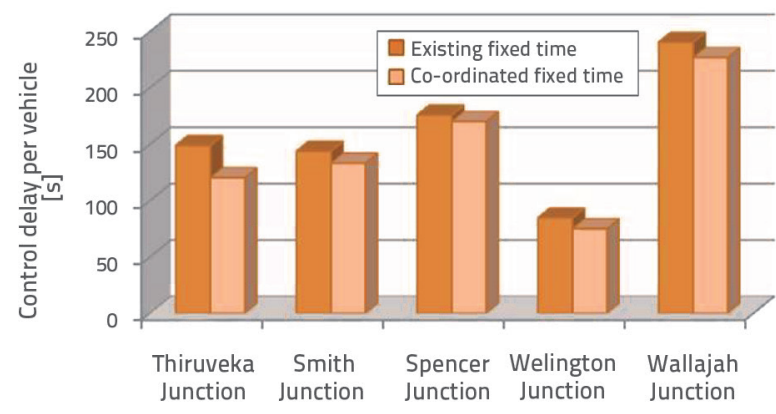

Figure 7. Comparision of fixed time with fixed time coordination

\section{Acknowledgements}

Authors would like to expresses their sincere thanks to the Centre of Excellence (CoEUT) in Urban Transport of IITM as facilities created with their financial support for "Study on Safety at Work Zones in Urban Areas" were used. We acknowledge the assistance of Chennai City Traffic Police for facilitating data collection to the first author.
[8] Mao, C., Pei, Y.: Phase and Timing Optimization at Actuatedcoordinated Signal Control Intersection. ICCTP 2009: Critical Issues in Transportation Systems Planning, Development, and Management. (doi: 10.1061/(ASCE)0733-947X(1991)117:4(398))

[9] Cassidy, M., Coifman, B.: Design of a Machine Vision-Based, Vehicle Actuated Traffic Signal Controller. California PATH Research Report, 1998.

[10] Newell, G.F.: Vehicle-Actuated Control of a Diamond Interchange. Institute of Transportation Studies (UCB), UC Berkeley,1998.

[11] Jun Ding, Qing He.: Development and Testing of Priority Control System in Connected Vehicle Environment. TRB $92^{\text {th }}$ Annual Meeting at Washington, D.C. January 2013

[12] Ko, J., Hunter, M.P., Guensler, R.L.: Measuring control delay using second - by - second GPS speed data, Transportation Research Board 2007., Annual Meeting CD- ROM(2007).

[13] Robertson, H.D., Hummer, J.E., Nelson, D.C.: "Manual of Transportation Engineering Studies", Institute of Transportation Engineers, Washington, USA, 1994. 